IRA-International Journal of Management \& Social Sciences

ISSN 2455-2267; Vol.04, Issue 02 (2016)

Pg. no. 339-357

Institute of Research Advances

http://research-advances.org/index.php/RAJMSS

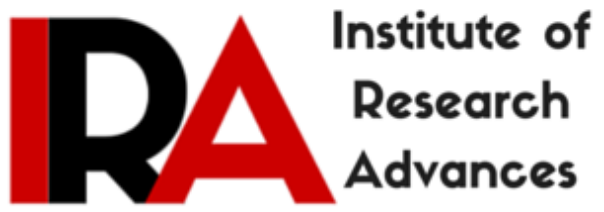

\title{
Organisational Effectiveness of NGOs with Reference to Personal Characteristics of Staff
}

\author{
Dr. K. Balaraju \\ Assistant Professor (c) \\ Department of Social Work \\ Osmania University, Hyderabad, India .
}

Type of Review: Peer Review

DOI: http://dx.doi.org/10.21013/jmss.v4.n2.p4

\section{How to cite this paper:}

Balaraju, K. (2016). Organisational Effectiveness of NGOs with Reference to Personal Characteristics of Staff. IRA-International Journal of Management \& Social Sciences (ISSN 2455-2267), 4(2), 339-357. doi:http://dx.doi.org/10.21013/jmss.v4.n2.p4

(C) Institute of Research Advances

(c) ) EY-NC

This work is licensed under a Creative Commons Attribution-Non Commercial 4.0 International License subject to proper citation to the publication source of the work.

Disclaimer: The scholarly papers as reviewed and published by the Institute of Research Advances (IRA) are the views and opinions of their respective authors and are not the views or opinions of the IRA. The IRA disclaims of any harm or loss caused due to the published content to any party. 


ABSTRACT
Measuring Organisation effectiveness in the perspective of NGOs staff can give more effective
feedback, with this feedback NGOs can able to know the strengths and weaknesses in given
dimensions. The present study attempts to analyse an organizational effectiveness of NGOs as
perceived by staff. The data have been collected from ten NGOs working in Telangana, India. Select
NGOs identified by using Stratified disproportionate sampling method in which 100 staff members
from 10 NGOs have responded. This study uses the standardised 28 items scale i.e. NGOs
Effectiveness Instrument (NEI) to measure the Organisational effectiveness developed by Swapan
Garian(1993) additionally 3 items have been included in the instrument. The result indicated that
organisational effectiveness of NGOs affected by NGOs staff personal characteristics namely gender,
age, professional qualification, designation, place of work and work experience. The reasons have
also been discussed.

Keywords: Organisational Effectiveness, NGO, NGO staff Personal Characteristics, NEI.

\subsection{Introduction}

The growth of NGOs over the past three decades has given an increasingly important role to perform within civil society. Most of the sociologists define NGOs as organisations which posses' four defining characteristics which enable them to be distinguished from other organizations in civil society. They are; voluntary, independent, not-for profit, self-serving. (Edwards \& Hulme, 1989) governments have been outsourcing more of their development aid delivery to NGOs, following a trend amongst all organizations to outsource non-core functions (Mullin, 1996). At the same time, a reduction in communication costs has made it easier and cheaper for entrepreneurs in the NGOs to organize. NGOs were preferred because of their special characteristics like small size, more participatory, less bureaucratic, more flexible, cost effectiveness and so on (Baru, 1998; Rajasekhar, 2000). From the learning and experiences the non-governmental organisations have been improving their working standards. These organisations trying to work more professionally but there is an argument that NGOs still have not shown satisfactory progress and therefore the question effectiveness of NGOs is arose. If organizations are to survive and achieve long-run viability, they must be effective.

Most NGOs are small in size. They lack easy access to the specialist knowledge they require. For example, they may be aware that 'staff development' is important, but have little idea about how to do it (Moore \& Stewart, 1998). Non-governmental Organisation activities are innovative and experimental rather than routine, in such circumstances measuring organisatioal effectiveness or evaluating NGO effectiveness is a not an easy one.

\subsection{Organisational Effectiveness of NGOs}

Nongovernment organizations effectiveness is intended to identify and describe some of the key components in creating and maintaining successful non-profit organizations. Furthermore, it is intended to create a framework for developing creative tools to measure organizational effectiveness of Nongovernmental Organisations. Organisational effectiveness influences the organisation performance in goal achievement, stakeholder's satisfaction and innovation and expertise solutions in their area of operation. In the present study OE is defined for the purpose of evaluating NGOs effectiveness.

Organisation Effectiveness is defined on the basis of Swapan Garain's (1993) NGOs Effectiveness Instrument (NEI), which is described various Organisation Effectiveness dimensions. In this view Organisation Effectiveness is multi-dimensional as it has to address the various concerns of the organisation activities including management of the organisation, programme delivery, appropriate utilization of resources and other aspects of project implementation to achieve the project goals or organisation objectives. 
The important dimensions of OE like "Agency Appreciation", "Programme Effectiveness", "Innovativeness", "Target Group Involvement", "Resource Appreciation", "Project Orientation", and "Organisation Flexibility" can give the overall effectiveness of Non-governmental organisation.

\subsection{NGO Staff}

Generally Non-governmental Organisations are largely staffed by altruistic employees and volunteers working towards ideological rather than financial end. NGOs staff defined on the basis of their employee's nature of work, designation and their involvement in all the stages of project cycle and other management aspects of the organisation.

According to their roles and responsibilities NGOs staff is defined as "The managers of organisations like chief functionaries, Executive directors, project team leaders, coordinators, technical persons, social mobilisers, community organizers and other field level functionaries of NGOs are called as NGO staff', all these functionaries perform their duties either field or office, or at both places and getting remuneration for their services from the organisation.

\subsection{Significance of the Study}

The present study is important for four main reasons, firstly assessing the organisational effectiveness of NGOs. Such efforts will help in designing organisations which can focus more effectively on planned outcomes. Such outcomes might improve the socio economic status of the beneficiaries and eventually provide quality of life experiences. Secondly understanding the organisational effectiveness of NGOs in three distinct districts of Telangana greatly contributes to the regional development and also to the beneficiaries of the region, besides the organisational mandate also suggests the need for evaluation of NGOs in the form of accountability to the donors. Since every donor while supporting an NGO financially, expects reports of organizational effectiveness and its impact on beneficiaries. Thus the variations in NGOs organisational effectiveness have been studied. Lastly, the study also contributes to understanding the NGOs effectiveness according to the personal characteristics of staff at various levels.

\subsection{Review of Literature}

Thorndike (1949) first noted the general trend among the organisational researchers to assess organisational effectiveness using a univariate model that focused on an ultimate criterion, such as profit or productivity. This approach directed towards organisational outcomes and viewed the organisation as a rational system that enables the attainment of certain objectives.

Georgopolous and Tannenbaum (1957) shifted the focus from univariate to multivariate with their attempt to expand the list of criteria to include organisation flexibility and intraorganisational strain based on their empirical investigation of an industrial firm's effectiveness.

Ghorpade (1971) found that "Organizational effectiveness" is a phrase used almost exclusively by researchers. It is less widely used in texts for the individual non-profit manager or practitioner. $\mathrm{OE}$ was first found in organizational behaviour theory of 1950s. In his view OE is defined as a process of "fulfilling objectives without incapacitating means"

Swapan Garain (1998) presented a volume, which adopts organizational behavior approach in developing conceptual and methodological perspective to understand the behavioural dynamics and effectiveness of NGOs. This book is based on a study of Twenty Nongovernmental organizations, study reveals the relationship across the range of individual, organization factors for developing and understanding of the dynamics of the NGO behaviour, this is one of few studies, which have delved in to the organisational dynamics of Non-Government Organisations. A standardized scale to measure effectiveness of NGOs developed by Swpan Garian (1993). This scale measures 8 dimensions of effectiveness of NGOs. 
Sowa, Coleman Selden and Sandfort (2004) proposed a multi-dimensional and integrated model of nonprofit organisational effectiveness (MIMNOE). This model had two focuses: management effectiveness and program effectiveness. These were further broken down into performance measures or outcomes.

Kaldor \& Schiller (2005), stated nongovernment organizations (NGOs) and civil society organizations have been established in significant numbers worldwide in the past decades. While play more importance roles in social services, the NGOs are becoming more practical, flexible and less strict.

According to Scriven (2007), Organisational evaluations may come from a variety of valid sources, including an understanding of the nature of the organisation, organisation needs, professional standards, logical analysis, legal requirements, ethical requirements, factual and definitional premises, organisational goals or desires, articulated by the dominant coalition, cultural or traditional standards, risk, marketability and resource economy.

Reynolds (2007) observed that the effectiveness of an organisation depends on the actual boundary judgements associated with the system. Therefore evaluating a system of interest requires identifying the boundary judgments. The limitations of this approach relate to its measurement of means.

Brown (2008), concluded that Effectiveness as a measure of organizational success has for decades attracted scholarly attention from across the social sciences. More recently, the issue of effectiveness has taken on additional urgency amongst practitioners due to increasing demands for accountability, transparency and financial responsibility

According to Balduck and Buelens (2008), the issue of effectiveness in organizations revolves round four main approaches: the system resource approach, the goal approach, the strategic constituency approach and the internal process approach. These are effective and efficient approaches which are contingent upon the type of situation to arise.

Literature highlights that NGOs are in fact playing a role in helping beneficiaries to achieve human development. The review also finds that the majority of articles on NGO effectiveness lack empirical analysis. The classified articles sampled as being primarily "theory or framing articles." by comparison, the next largest categories "program evaluation" and "case studies", included only a few articles respectively. This suggests that the majority of academic work on effectiveness focuses on advancing theory or framing the research agenda rather than using empirical evidence.

In view of the above, the present study attempts to assess the organisational effectiveness of NGOs in various dimensions as perceived by their managers and their employees in selected three districts of Telangana to have a comparative picture. The present study does not deal with the evaluation of the programmes conducted by the NGOs, but the evaluations of NGOS in the perspective of how effective are they as organisations in the eyes of their employees. The objectives and hypotheses formulated were presented in order to enumerate the directions to the study.

\subsection{Objectives of the Study}

1. To understand the dimensions of organizational effectiveness of NGOs

2. To analyze the perceptions of the NGOs staff towards organizational effectiveness according to their personal characteristics.

\subsection{Hypotheses of the Study}

In view of the proposed objective, the following hypotheses are formulated in null form. 
$\mathrm{H}$ : There is no variation in perceived organisational effectiveness of NGOs according to the personal characteristics of NGOs staff. The personal characteristics studied include Gender, Age, Professional qualification, Designation, Place of work and Work experience.

\subsection{Methodology of the study}

Using descriptive and analytic research design, this study addresses the organizational effectiveness of NGOs and the influence of personal characteristics of NGOs staff towards the organizations effectiveness. Therefore, the status of effectiveness of NGOs and the influence of personal characteristics of NGOs staff are examined.

\subsection{Sample Design}

The present study is carried out in three districts of Telangana. They are Khammam, Nalgonda and Mahabubnagar. As three distinct districts of Telangana have been identified by using standard stratification process, the selection of NGOs has been the last phase of sampling. Details are presented in the table 1 .

Table 1: Sample of the study

\begin{tabular}{|c|l|c|c|c|c|}
\hline S.No & $\begin{array}{l}\text { Name of the } \\
\text { District }\end{array}$ & $\begin{array}{l}\text { No.of } \\
\text { NGOs }\end{array}$ & $\begin{array}{l}\text { Chief } \\
\text { Functionary }\end{array}$ & $\begin{array}{l}\text { NGOs } \\
\text { staff }\end{array}$ & $\begin{array}{l}\text { Total } \\
\text { NGOs } \\
\text { Staff }\end{array}$ \\
\hline 1 & Khammam & 3 & 3 & 27 & 30 \\
\hline 2 & Nalgonda & 3 & 3 & 27 & 30 \\
\hline 3 & Mahabubnagar & 4 & 4 & 36 & 40 \\
\hline \multicolumn{2}{r|}{ TOTAL } & 10 & 10 & 90 & 100 \\
\hline
\end{tabular}

(Source: Primary Data)

Using stratified disproportionate random sampling method ten NGOs were selected for the study from Telangana. From each NGO one chief functionary and nine staff members were selected from various middle and lower levels. In this way, the total number of sample NGOs three each from Khammam district, Nalgonda district and four from the Mahabubnagar district. The total number of staff members from all the three districts is one hundred. The Profile of select Non-Government Organizations in Telangana were presented in following table 2. 
Table 2: Profile of Select NGOs in Telangana

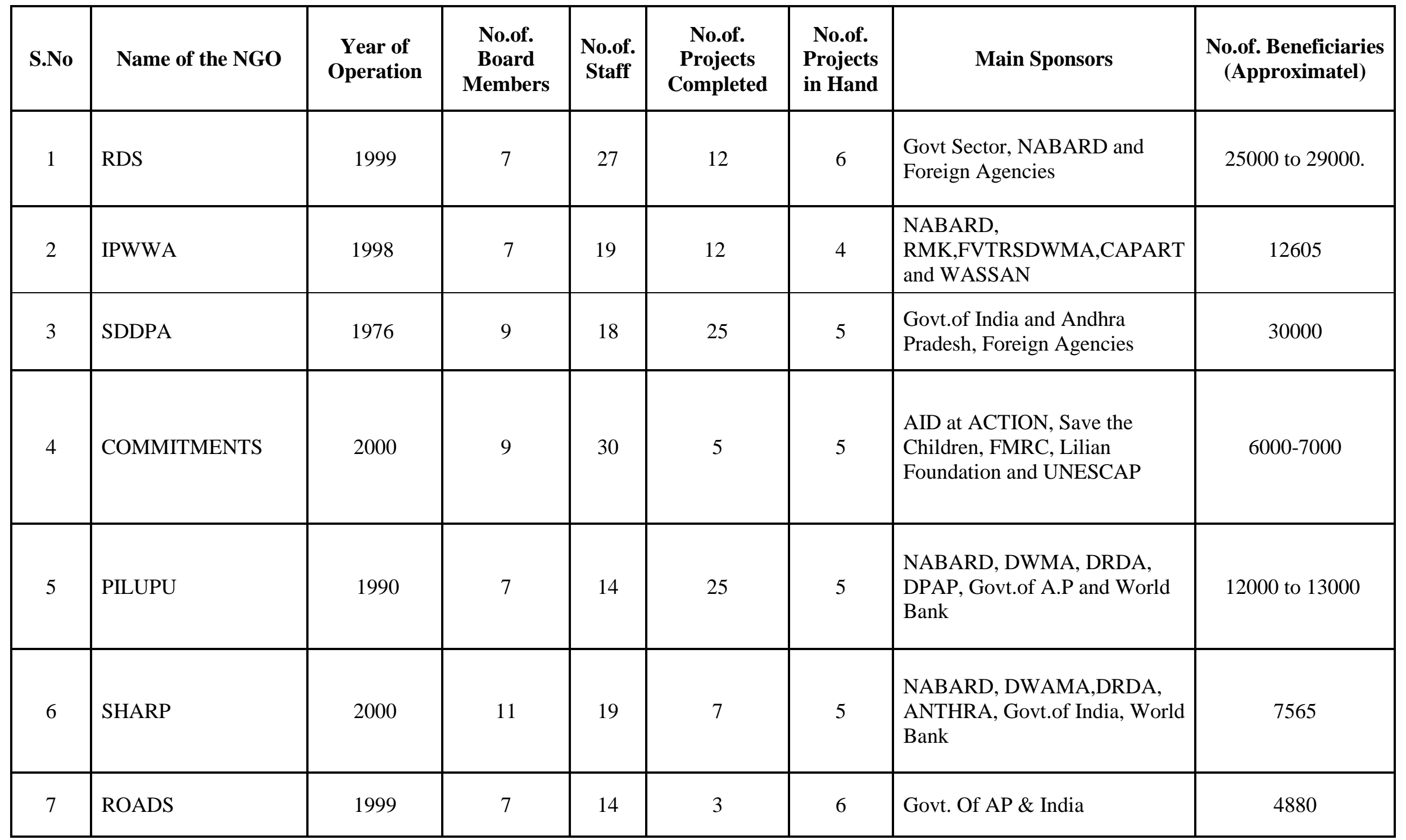




\begin{tabular}{|c|l|c|c|c|c|c|l|}
8 & ASDS & 1985 & 7 & 144 & 20 & 3 & NABARD, Action AID \\
\hline 9 & MORE & 1993 & 7 & 45 & 4 & 4 & $\begin{array}{l}\text { NACO, ECO, AID at Action } \\
\text { and RVM }\end{array}$ \\
\hline 10 & AID & 1991 & 11 & 18 & 15 & 3 & $\begin{array}{l}\text { RVM, AP Housing Corporation, } \\
\text { CADA }\end{array}$ \\
\hline Average & & & 8.2 & 34.8 & 12.8 & 4.6 & Total \\
\hline
\end{tabular}

(Computed from Primary Data)

As can be observed from the table 2 by the columns, the NGOs under study started their operation between 1985 and all 2000. The average number of board members of these NGOs is 8.2 numbers, followed by the average staff size is 34.8 on an average, these NGOs have completed 13 projects so far since this establishment besides, an on average, and they have about 4.6 projects in hand. Lastly, the average size of the beneficiaries of these NGOs is 12605.

\subsection{Methods and Tools of Data Collection}

A standardized questionnaire for NGO staff consists of two parts was developed. Part A consists of personal background variables for the staff member to respond. Part B includes a standardized 28 items scale to measure Organisation Effectiveness of NGOs developed by Swapan Garain (1993) additionally items namely "Our agency makes optimum utilization of resources", "Other resources (Material, staff, time etc)", "Time bound projects are always completed within the time frame in our Agency", "Our agency is prompt in responding to changing circumstances" have been included.

\subsection{Analysis of Results}

\section{Organisational Effectiveness of NGOs According to the Personal Characteristics of the Staff}

Data pertaining to the perceived effectiveness of NGOs according to the personal characteristics of the NGOs staff, in all the eight dimensions of Organisational effectiveness were collected. Results in this regard were presented in following table 3.

\subsection{Effectiveness of NGOs According to the Gender}

Data pertaining to the gender of the respondents and effectiveness of NGOs in all the dimensions were collected. Results in this regard were presented in Table6.3. 
Table 3: Effectiveness of NGOs by Gender

\begin{tabular}{|c|c|c|c|c|c|c|c|c|}
\hline S.No & Dimension & $\mathbf{M} / \mathbf{F}$ & $\mathbf{N}$ & Mean & $\begin{array}{c}\text { Std. } \\
\text { Deviation }\end{array}$ & $\begin{array}{c}\mathbf{F} \\
\text { value }\end{array}$ & d.f & $\mathbf{P}=$ \\
\hline \multirow{2}{*}{1} & \multirow{2}{*}{$\begin{array}{l}\text { Agency } \\
\text { Appreciation }\end{array}$} & Male & 76 & 18.08 & 0.69 & \multirow{2}{*}{16.28} & \multirow{2}{*}{1,98} & \multirow{2}{*}{0.00} \\
\hline & & Female & 24 & 18.67 & 0.33 & & & \\
\hline \multirow{2}{*}{2} & \multirow{2}{*}{$\begin{array}{l}\text { Program } \\
\text { Effectiveness }\end{array}$} & Male & 76 & 19.47 & 0.45 & \multirow{2}{*}{7.96} & \multirow{2}{*}{1,98} & \multirow{2}{*}{0.006} \\
\hline & & Female & 24 & 19.88 & 0.99 & & & \\
\hline \multirow{2}{*}{3} & \multirow{2}{*}{ Innovation } & Male & 76 & 15.88 & 1.88 & \multirow{2}{*}{6.26} & \multirow{2}{*}{1,98} & \multirow{2}{*}{0.01} \\
\hline & & Female & 24 & 14.67 & 2.59 & & & \\
\hline \multirow{2}{*}{4} & \multirow{2}{*}{$\begin{array}{l}\text { Grassroots } \\
\text { Impact }\end{array}$} & Male & 76 & 19.57 & 1.69 & \multirow{2}{*}{4.77} & \multirow{2}{*}{1,98} & \multirow{2}{*}{0.03} \\
\hline & & Female & 24 & 18.75 & 3.28 & & & \\
\hline \multirow{2}{*}{5} & \multirow{2}{*}{$\begin{array}{l}\text { Target Group } \\
\text { Involvement }\end{array}$} & Male & 76 & 12.03 & 1.33 & \multirow{2}{*}{32.08} & \multirow{2}{*}{1,98} & \multirow{2}{*}{0.00} \\
\hline & & Female & 24 & 11.63 & 1.78 & & & \\
\hline \multirow{2}{*}{6} & \multirow{2}{*}{$\begin{array}{l}\text { Resource } \\
\text { Appreciation }\end{array}$} & Male & 76 & 11.33 & 1.55 & \multirow{2}{*}{13.06} & \multirow{2}{*}{1,98} & \multirow{2}{*}{0.00} \\
\hline & & Female & 24 & 11.88 & 0.94 & & & \\
\hline \multirow{2}{*}{7} & \multirow{2}{*}{$\begin{array}{l}\text { Project } \\
\text { Orientation }\end{array}$} & Male & 76 & 10.34 & 1.49 & \multirow{2}{*}{11.86} & \multirow{2}{*}{1,98} & \multirow{2}{*}{0.001} \\
\hline & & Female & 24 & 9.92 & 1.61 & & & \\
\hline \multirow{2}{*}{8} & Organization & Male & 76 & 11.11 & 1.58 & 1685 & 108 & O 00 \\
\hline & Flexibility & Female & 24 & 11.25 & 1.89 & 10.85 & 1,98 & 0.00 \\
\hline
\end{tabular}

(Computed from Primary Data)

The table 3 Presented mean scores and Std. Deviation pertaining to the Effectiveness of NGOs with respect to the gender of the staff as perceived by the respondents from all the developmental blocks (Under developed, developing and developed) of the Telangana region.

As regards dimensions of effectiveness of NGOs of the gender of the NGOs staff female are perceived in the dimensions of better namely "Agency Appreciation" (18.67), "Programme Effectiveness" (19.58), "Resource Appreciation"(11.88) and "Organisation Flexibility" (11.25), than male.

For further examination it is interestingly to note that male are perceived better in dimensions namely "Innovation" (15.88), "Grassroots Impact" (19.57), "Target Group Involvement"(12.03) and "Project Orientation" (11.25).

The Univarite ANOVA test were conducted for each dependent Variable, The above shown results proved all the organisation effectiveness dimensions namely "Agency Appreciation", "Programme Effectiveness", "Innovation", "Grassroots impact", "Target Group Involvement", "Resource Appreciation, "Project Orientation and Finally Organisation flexibility significantly affected by Organisation effectiveness with respect to the gender as evident from the F values presented in the table.

\subsection{Effectiveness of NGOs According to the Age}

Data pertaining to the age of the respondents and effectiveness of NGOs in all the dimensions were collected. Results in this regard were presented in Table 4. 
Table 4: Effectiveness NGOs by Age

\begin{tabular}{|c|c|c|c|c|c|c|c|c|}
\hline S.No & Dimension & Age & $\mathbf{N}$ & Mean & $\begin{array}{c}\text { Std. } \\
\text { Deviation }\end{array}$ & $\begin{array}{c}F \\
\text { value }\end{array}$ & d.f & $\mathbf{P}=$ \\
\hline \multirow{3}{*}{1} & \multirow{3}{*}{$\begin{array}{l}\text { Agency } \\
\text { Appreciation }\end{array}$} & $18-25$ & 13 & 18.08 & 1.06 & \multirow{3}{*}{3.79} & \multirow{3}{*}{2,99} & \multirow{3}{*}{0.02} \\
\hline & & $26-38$ & 63 & 17.95 & 1.58 & & & \\
\hline & & $39-62$ & 24 & 19 & 1.87 & & & \\
\hline \multirow{3}{*}{2} & \multirow{3}{*}{$\begin{array}{l}\text { Program } \\
\text { Effectiveness }\end{array}$} & $18-25$ & 13 & 19.31 & 0.38 & \multirow{3}{*}{3.32} & \multirow{3}{*}{2,99} & \multirow{3}{*}{0.04} \\
\hline & & $26-38$ & 63 & 19.43 & 0.67 & & & \\
\hline & & $39-62$ & 24 & 19.79 & 0.70 & & & \\
\hline \multirow{3}{*}{3} & & $18-25$ & 13 & 14.92 & 1.19 & \multirow{3}{*}{2.97} & \multirow{3}{*}{2,99} & \multirow{3}{*}{0.05} \\
\hline & & $26-38$ & 63 & 15.78 & 1.21 & & & \\
\hline & Innovation & $39-62$ & 24 & 15.46 & 1.16 & & & \\
\hline \multirow{3}{*}{4} & \multirow{3}{*}{$\begin{array}{l}\text { Grassroots } \\
\text { Impact }\end{array}$} & $18-25$ & 13 & 20.23 & 1.23 & \multirow{3}{*}{4.64} & \multirow{3}{*}{2,99} & \multirow{3}{*}{0.01} \\
\hline & & $26-38$ & 63 & 19.33 & 1.22 & & & \\
\hline & & $39-62$ & 24 & 19 & 1.05 & & & \\
\hline \multirow{3}{*}{5} & \multirow{3}{*}{$\begin{array}{l}\text { Target Group } \\
\text { Involvement }\end{array}$} & $18-25$ & 13 & 11.54 & 0.19 & \multirow{3}{*}{5.84} & \multirow{3}{*}{2,99} & \multirow{3}{*}{0} \\
\hline & & $26-38$ & 63 & 12.03 & 0.41 & & & \\
\hline & & $39-62$ & 24 & 11.88 & 0.70 & & & \\
\hline \multirow{3}{*}{6} & \multirow{3}{*}{$\begin{array}{l}\text { Resource } \\
\text { Appreciation }\end{array}$} & $18-25$ & 13 & 11.23 & 0.30 & \multirow{3}{*}{4.25} & \multirow{3}{*}{2,99} & \multirow{3}{*}{0.01} \\
\hline & & $26-38$ & 63 & 11.48 & 0.54 & & & \\
\hline & & $39-62$ & 24 & 11.6 & 0.28 & & & \\
\hline \multirow{3}{*}{7} & \multirow{3}{*}{$\begin{array}{l}\text { Project } \\
\text { Orientation }\end{array}$} & $18-25$ & 13 & 9.92 & 0.84 & \multirow{3}{*}{10.71} & & \\
\hline & & $26-38$ & 63 & 10.43 & 0.38 & & 2,99 & 0.00 \\
\hline & & $39-62$ & 24 & 9.92 & 0.66 & & & \\
\hline & & $18-25$ & 13 & 11.71 & 0.43 & & & \\
\hline 8 & Organization & $26-38$ & 63 & 11.16 & 0.66 & 5.06 & 2,99 & 0.004 \\
\hline & Flexibility & $39-62$ & 24 & 11 & 0.76 & & & \\
\hline
\end{tabular}

(Computed from Primary Data)

The 4 table Presented mean scores and Std. Deviation of NGOs effectiveness with respect to age of the NGOs staff as perceived by respondents in all the developmental blocks (under developed, developing and developed) of Telangana region.

As regards dimensions of effectiveness of NGOs staff age group between 39 to 62 years are perceived the dimensions of better namely "Agency Appreciation" (19), "Programme Effectiveness" (19.79), "Resource Appreciation" (11.54), followed by the staff age group between 26 to 38 are perceived the dimensions of better namely "Innovation" (15.78), "Target Group Involvement" (12.03), Project Orientation" (10.43) than other age groups. Lastly it is interesting to note that the age group between 18 to 25 are perceived the dimensions of better namely "Grassroots Impact" (20.23), "Organisation Flexibility “ (11.31).

The univariate ANNOVA test were conducted for each dependent variable, it is observed that all eight dimensions of NGO effectiveness namely "Agency Appreciation", "Program Effectiveness", "Innovation", "Grassroots Impact", "Target Group Involvement", "Resource Appreciation", "Project Orientation", and "Organisation flexibility" were significantly affected by age as it is evident from the $\mathrm{f}$ values presented in the table. 


\section{3: Effectiveness of NGOs According to the Professional Qualification}

Data pertaining to the professional qualification of the respondents and effectiveness of NGOs in all the dimensions were collected. Results in this regard were presented in Table 5 .

Table 5: Effectiveness of NGOs by Professional Qualification

\begin{tabular}{|c|c|c|c|c|c|c|c|c|}
\hline S.No & Dimension & Professional Qualification & $\mathbf{N}$ & Mean & $\begin{array}{c}\text { Std. } \\
\text { Deviation }\end{array}$ & $\begin{array}{c}\mathbf{F} \\
\text { value }\end{array}$ & d.f & $\mathbf{P}=$ \\
\hline \multirow{5}{*}{1} & \multirow{5}{*}{$\begin{array}{l}\text { Agency } \\
\text { Appreciation }\end{array}$} & $\begin{array}{l}\text { Not Having any Professional } \\
\text { Qualification }\end{array}$ & 14 & 17.79 & 1.71 & \multirow{5}{*}{2.84} & \multirow{5}{*}{4,95} & \multirow{5}{*}{0.02} \\
\hline & & MA/M.Com/M.Sc/MSW/MBA/MCA & 15 & 18.27 & 1.53 & & & \\
\hline & & BA/B.Com/B.Sc/BSW/BCA/B.Tech & 56 & 18.5 & 1.65 & & & \\
\hline & & Diploma Courses or Intermediate & 11 & 18.18 & 1.94 & & & \\
\hline & & B.Ed and Other Courses & 4 & 15.75 & 1.25 & & & \\
\hline \multirow{5}{*}{2} & \multirow{5}{*}{$\begin{array}{l}\text { Program } \\
\text { Effectiveness }\end{array}$} & $\begin{array}{l}\text { Not Having any Professional } \\
\text { Qualification }\end{array}$ & 14 & 18.43 & 1.63 & \multirow{5}{*}{2.45} & \multirow{5}{*}{4,95} & \multirow{5}{*}{0.05} \\
\hline & & MA/M.Com/M.Sc/MSW/MBA/MCA & 15 & 19.33 & 1.58 & & & \\
\hline & & BA/B.Com/B.Sc/BSW/BCA/B.Tech & 56 & 19.64 & 1.4 & & & \\
\hline & & Diploma Courses or Intermediate & 11 & 20.18 & 1.27 & & & \\
\hline & & B.Ed and Other Courses & 4 & 20 & 0 & & & \\
\hline \multirow{5}{*}{3} & \multirow{5}{*}{ Innovation } & $\begin{array}{l}\text { Not Having any Professional } \\
\text { Qualification }\end{array}$ & 14 & 14.07 & 2.52 & \multirow{5}{*}{4.3} & \multirow{5}{*}{4,95} & \multirow{5}{*}{0.00} \\
\hline & & MA/M.Com/M.Sc/MSW/MBA/MCA & 15 & 14.67 & 1.23 & & & \\
\hline & & BA/B.Com/B.Sc/BSW/BCA/B.Tech & 56 & 16.09 & 2.04 & & & \\
\hline & & Diploma Courses or Intermediate & 11 & 16.45 & 1.69 & & & \\
\hline & & B.Ed and Other Courses & 4 & 15 & 2.30 & & & \\
\hline \multirow{2}{*}{4} & \multirow{2}{*}{$\begin{array}{l}\text { Grassroots } \\
\text { Impact }\end{array}$} & $\begin{array}{l}\text { Not Having any Professional } \\
\text { Qualification }\end{array}$ & 14 & 18 & 1.93 & \multirow{2}{*}{4.06} & \multirow{2}{*}{4,95} & \multirow{2}{*}{0.004} \\
\hline & & MA/M.Com/M.Sc/MSW/MBA/MCA & 15 & 19.47 & 1.88 & & & \\
\hline
\end{tabular}


IRA-International Journal of Management \& Social Sciences

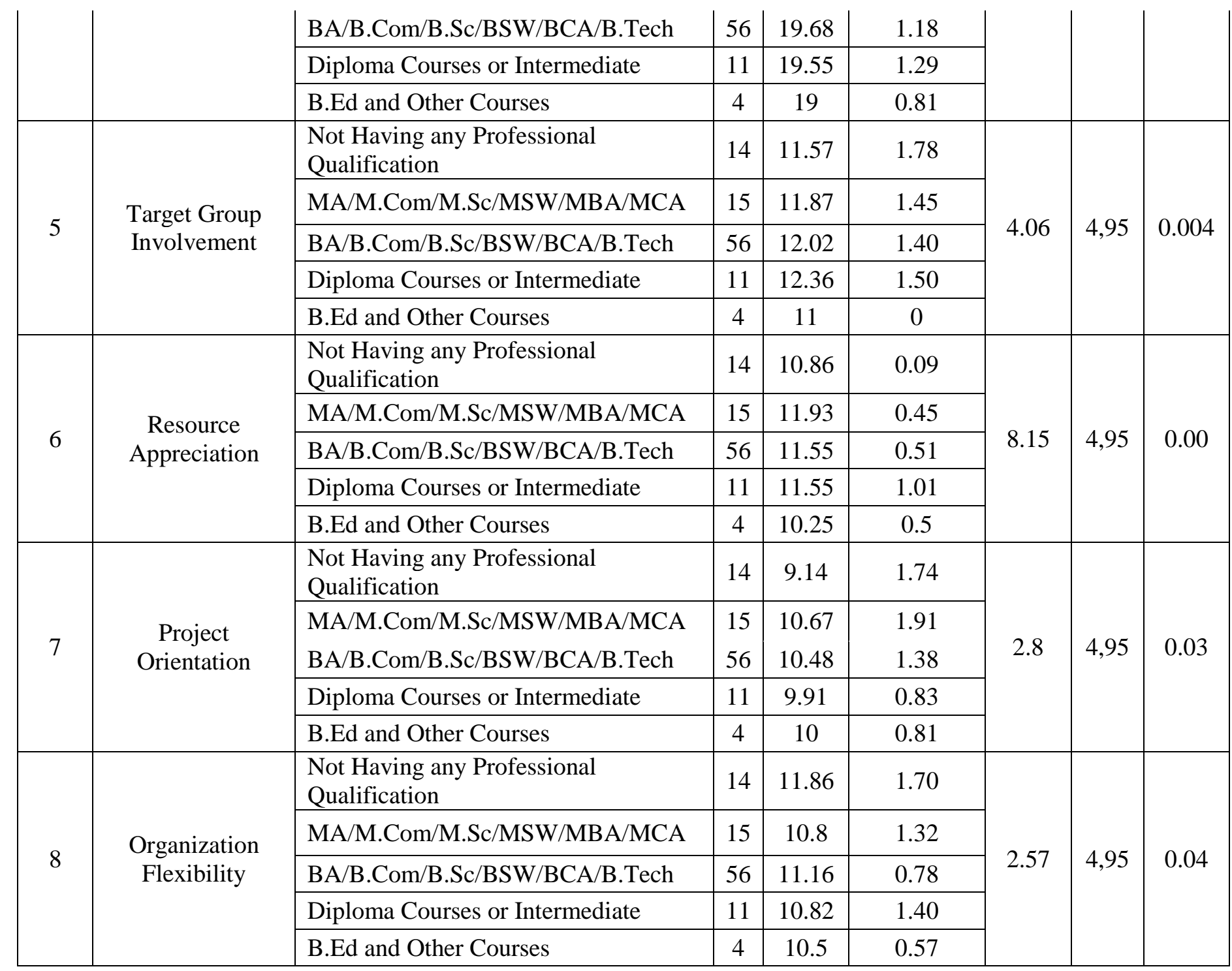

(Computed from Primary Data) 
The table 5 Presented mean scores and Std. Deviation pertaining to the Effectiveness of NGOs with respect to the Professional qualification as perceived by NGO staff members in all the developmental blocks (under developed, developing and developed) of Telangana region.

As regards dimensions of effectiveness of NGOs the staff professional qualifications of Diploma and Intermediate courses are perceived on the dimensions of better namely "Programme Effectiveness" (20.18), "Innovation" (16.45) and "Target Group Involvement" (12.36), followed by the professional qualification of the staff of MA/M.com/MSW/MCA/MBA/M.Sc are perceived the dimensions better namely "Resource Appreciation" (11.93), and "Project Orientation" (10.67). For further examination it is found that staff professional qualifications of BA/B.Com/B.Sc/BSW/BCA/B.Tech are perceived the dimensions of better namely "Agency Appreciation"(18.5) and "Grassroots Impact" (19.68).

Lastly, it is revealed from the above table mean scores that among the staff those who are not having any professional qualification are perceived the dimension of better namely "Organisation Flexibility" (11.86) than others.

The Univarite ANOVA test were conducted for each dependent Variable, The results shown above revealed that out of eight dimensions except six dimensions namely "Agency Appreciation", "Programme Effectiveness", "Grassroots Impact", "Target Group Involvement", "Resource Appreciation" and Finally Organisation Flexibility " and remaining dimensions namely innovation and project orientation significantly affected by the NGOs effectiveness and the Professional qualifications as evident from $\mathrm{F}$ values presented in the table

\subsection{Effectiveness of NGOs According to the Employees Designation}

In order to test the hypothesis "The employee's designation will not have significant effect on effectiveness of NGOs means and Standard deviations were computed for all the designations of NGOs employees in Telangana region. Further, to know the significance of the mean difference, F values were computed. Results in this regard were presented in the table 6.

Table 6: Effectiveness of NGOs by Designation

\begin{tabular}{|c|c|c|c|c|c|c|c|c|}
\hline S.No & Dimension & Designation & $\mathbf{N}$ & Mean & $\begin{array}{c}\text { Std. } \\
\text { Deviation }\end{array}$ & $\begin{array}{c}\text { F } \\
\text { Value }\end{array}$ & d.f & $\mathbf{P}=$ \\
\hline \multirow{5}{*}{1} & \multirow{5}{*}{$\begin{array}{l}\text { Agency } \\
\text { Appreciation }\end{array}$} & $\mathrm{CF} / \mathrm{ED}$ & 11 & 19.82 & 2.31 & \multirow{5}{*}{6.907} & \multirow{5}{*}{4,95} & \multirow{5}{*}{0.00} \\
\hline & & $\begin{array}{l}\text { Programme } \\
\text { Coordinator }\end{array}$ & 50 & 18.48 & 2.45 & & & \\
\hline & & $\begin{array}{l}\text { Project Manager or } \\
\text { Technical Person }\end{array}$ & 15 & 17.6 & 1.92 & & & \\
\hline & & $\begin{array}{l}\text { Social Mobiliser or } \\
\text { Community } \\
\text { Organiser }\end{array}$ & 12 & 19.33 & 2.93 & & & \\
\hline & & Teacher & 12 & 15.33 & 1.61 & & & \\
\hline \multirow{5}{*}{2} & \multirow{5}{*}{$\begin{array}{l}\text { Program } \\
\text { Effectiveness }\end{array}$} & $\mathrm{CF} / \mathrm{ED}$ & 11 & 21.36 & 2.24 & \multirow{5}{*}{7.197} & \multirow{5}{*}{4,95} & \multirow{5}{*}{0.00} \\
\hline & & $\begin{array}{l}\text { Programme } \\
\text { Coordinator }\end{array}$ & 50 & 19.1 & 2.74 & & & \\
\hline & & $\begin{array}{l}\text { Project Manager or } \\
\text { Technical Person }\end{array}$ & 15 & 19.93 & 2.15 & & & \\
\hline & & $\begin{array}{l}\text { Social Mobiliser or } \\
\text { Community } \\
\text { Organiser }\end{array}$ & 12 & 19.92 & 2.27 & & & \\
\hline & & Teacher & 12 & 18.5 & 2.19 & & & \\
\hline 3 & Innovation & $\mathrm{CF} / \mathrm{ED}$ & 11 & 16.64 & 2.15 & 6.025 & 4,95 & 0.00 \\
\hline
\end{tabular}




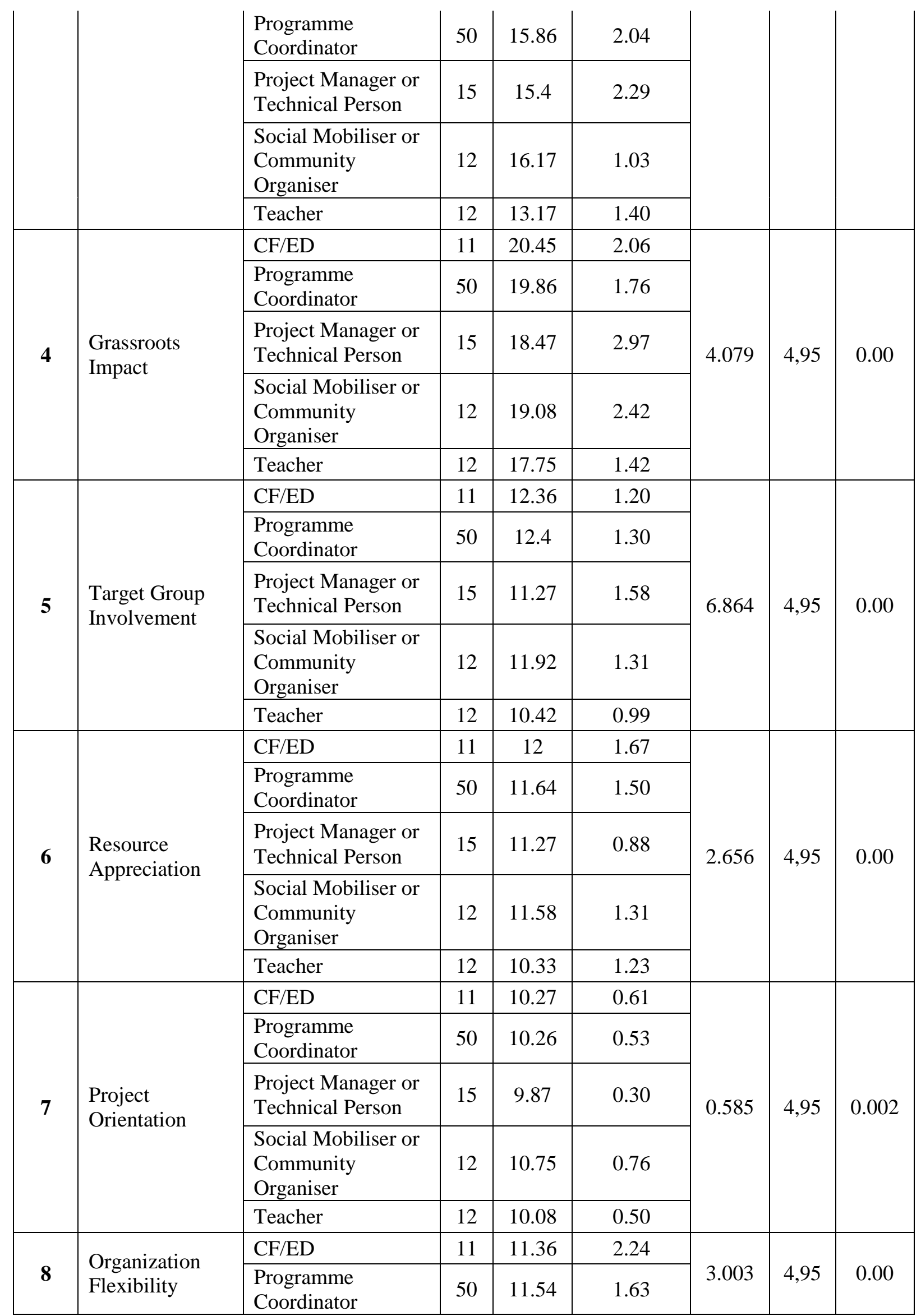




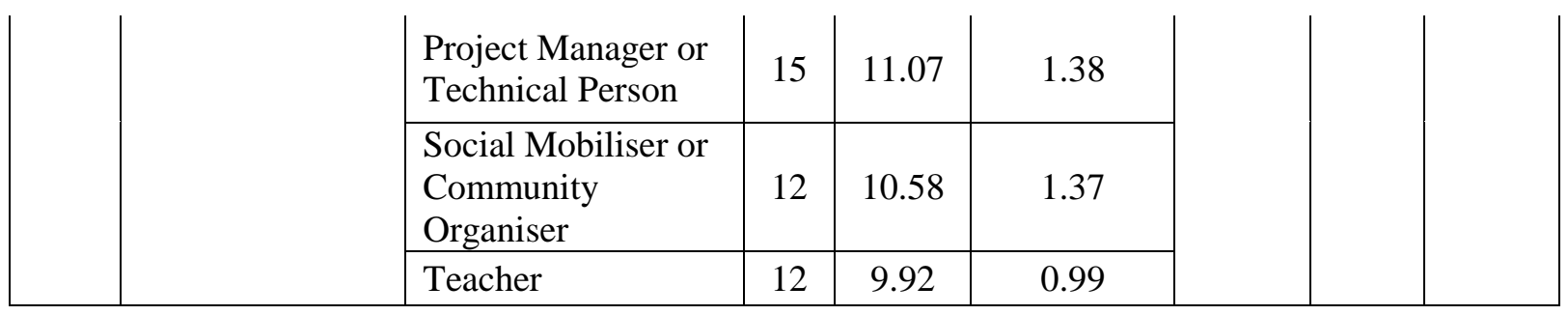

(Computed from Primary Data)

The table 6 presented pertaining to the Effectiveness of NGOs with respect to the designation of the staff as perceived by NGO staff members in all the developmental blocks (under developed, developing and developed) of Telangana region.

As regards dimensions of effectiveness of NGOs the staff designations of CF/ED are perceived the dimensions better namely "Agency Appreciation" (19.82), " Programme Effectiveness (21.36) , “ Innovation" (16.64), "Grassroots Impact" (20.45) , “ Resource Appreciation" (12 percent) . For further examination it is interestingly to note that "Programme Coordinators are perceived in the dimensions better namely “

Target Group Involvement" (12.4) and "Organisation Flexibility" (11.54) lastly, social mobilisers or community organisers perceived the dimensions of better namely "Project Orientation" (10.75) than other NGO staff designations.

The Univarite ANOVA test were conducted for each dependent variable, The results shown above revealed that there was a significant effect on organisation effectiveness dimensions namely " Agency Appreciation", "Project Orientation", "Programme Effectiveness", "Innovation", "Grassroots Impact" "Target Group Involvement', "Resource Appreciation", "Organisation Flexibility". It clearly shows that there is a significant effect on the NGO effectiveness and the staff Designations.

\subsection{Effectiveness NGOs according to the Place of Work}

Data pertaining to the place of work (office/field/both (office and field) of the respondents and effectiveness of NGOs in all the dimensions were collected. Results in this regard were presented in Table 7.

Table 7: Effectiveness of NGOs by Place of Work

\begin{tabular}{|c|c|c|c|c|c|c|c|c|}
\hline S.No & Dimension & $\begin{array}{l}\text { Place of } \\
\text { Work }\end{array}$ & $\mathbf{N}$ & Mean & $\begin{array}{c}\text { Std. } \\
\text { Deviation }\end{array}$ & $\begin{array}{c}\mathbf{F} \\
\text { value }\end{array}$ & d.f & $\mathbf{P}=$ \\
\hline \multirow{3}{*}{1} & \multirow{3}{*}{$\begin{array}{l}\text { Agency } \\
\text { Appreciation }\end{array}$} & Office & 6 & 16.67 & 1.86 & \multirow{3}{*}{3.89} & \multirow{3}{*}{2,99} & \multirow{3}{*}{0.02} \\
\hline & & Field & 21 & 17.86 & 1.90 & & & \\
\hline & & Both & 73 & 18.45 & 1.55 & & & \\
\hline \multirow{3}{*}{2} & \multirow{3}{*}{$\begin{array}{l}\text { Program } \\
\text { Effectiveness }\end{array}$} & Office & 6 & 22.17 & 0.98 & \multirow{3}{*}{8.34} & \multirow{3}{*}{2,99} & \multirow{3}{*}{0.00} \\
\hline & & Field & 21 & 19.62 & 1.85 & & & \\
\hline & & Both & 73 & 19.25 & 1.72 & & & \\
\hline \multirow{3}{*}{3} & \multirow{3}{*}{ Innovation } & Office & 6 & 15.5 & 2.58 & \multirow[t]{3}{*}{2.968} & \multirow[t]{3}{*}{2,99} & \multirow[t]{3}{*}{0.056} \\
\hline & & Field & 21 & 14.62 & 2.78 & & & \\
\hline & & Both & 73 & 15.88 & 1.80 & & & \\
\hline
\end{tabular}




\begin{tabular}{|c|c|c|c|c|c|c|c|c|}
\hline \multirow{3}{*}{4} & \multirow{3}{*}{$\begin{array}{l}\text { Grassroots } \\
\text { Impact }\end{array}$} & Office & 6 & 18.17 & 1.72 & \multirow{3}{*}{3.263} & \multirow{3}{*}{2,99} & \multirow{3}{*}{0.043} \\
\hline & & Field & 21 & 18.57 & 3.50 & & & \\
\hline & & Both & 73 & 19.7 & 1.60 & & & \\
\hline \multirow{3}{*}{5} & \multirow{3}{*}{$\begin{array}{l}\text { Target Group } \\
\text { Involvement }\end{array}$} & Office & 6 & 10.5 & 1.64 & \multirow{3}{*}{7.344} & \multirow{3}{*}{2,99} & \multirow{3}{*}{0.001} \\
\hline & & Field & 21 & 11.29 & 1.79 & & & \\
\hline & & Both & 73 & 12.23 & 1.20 & & & \\
\hline \multirow{3}{*}{6} & \multirow{3}{*}{$\begin{array}{l}\text { Resource } \\
\text { Appreciation }\end{array}$} & Office & 6 & 10.5 & 1.22 & \multirow{3}{*}{3.14} & \multirow{3}{*}{2,99} & \multirow{3}{*}{0.04} \\
\hline & & Field & 21 & 11.24 & 1.23 & & & \\
\hline & & Both & 73 & 11.6 & 1.12 & & & \\
\hline \multirow{3}{*}{7} & \multirow{3}{*}{$\begin{array}{l}\text { Project } \\
\text { Orientation }\end{array}$} & Office & 6 & 9 & 1.54 & \multirow{3}{*}{3.08} & \multirow{3}{*}{2,99} & \multirow{3}{*}{0.05} \\
\hline & & Field & 21 & 10.48 & 0.80 & & & \\
\hline & & Both & 73 & 10.27 & 1.40 & & & \\
\hline \multirow{3}{*}{8} & \multirow{3}{*}{$\begin{array}{l}\text { Organization } \\
\text { Flexibility }\end{array}$} & Office & 6 & 10.33 & 0.63 & \multirow{3}{*}{6.93} & \multirow{3}{*}{2,99} & \multirow{3}{*}{0.00} \\
\hline & & Field & 21 & 11.38 & 0.91 & & & \\
\hline & & Both & 73 & 11.14 & 0.57 & & & \\
\hline
\end{tabular}

(Computed from Primary Data)

The table 7 Presented mean scores and Std. Deviation pertaining to the Effectiveness of NGOs with respect to the place work of the staff as perceived by NGO staff members in all the developmental blocks (under developed, developing and developed) of Telangana region.

As regards dimensions of effectiveness of NGOs staff place of work of those who are working at both in office and filed perceived the dimensions of better namely "Agency Appreciation" (18.45), "Innovation" (15.88), "Grassroots Impact" (19.7), Target Group Involvement" (12.23), and "Resource Appreciation" (11.6), followed by staff working at field only perceived the dimensions better namely "Project Orientation" (10.48) and "Organisation Flexibility" (11.14). Interestingly staff who are working at only office perceived the dimension of better namely "Programme Effectiveness" (22.17) than other staff members working at field and office and field only.

The Univarite ANOVA test were conducted for each dependent Variable, The results shown above revealed that out of eight dimensions except five dimensions namely "Agency Appreciation", "Innovation", "Resource Appreciation", "Project Orientation", "Organisation Flexibility" and remaining dimensions namely "Programme Effectiveness", "Grassroots impact" and Target group involvement" significantly affected by the place of work, as evident from F values presented in the table

\subsection{Effectiveness of NGOs according to the Work Experience}

Data pertaining to the work experience of the respondents and effectiveness of NGOs in all the dimensions were collected. Results in this regard were presented in Table 8.

Table 8: Effectiveness of NGOs by Work Experience

\begin{tabular}{|c|l|c|c|c|c|c|c|c|}
\hline S.No & Dimension & $\begin{array}{c}\text { Work } \\
\text { Experience } \\
\text { (in years) }\end{array}$ & $\mathrm{N}$ & Mean & $\begin{array}{c}\text { Std. } \\
\text { Deviation }\end{array}$ & $\begin{array}{c}\mathrm{F} \\
\text { value }\end{array}$ & d.f & $\mathrm{P}=$ \\
\cline { 1 - 7 } 1 & $\begin{array}{l}\text { Agency } \\
\text { Appreciation }\end{array}$ & 4 to 9 & 44 & 17.53 & 2.51 & \multirow{2}{*}{3.566} & 2,99 & 0.032 \\
\cline { 3 - 6 } & 10 to 33 & 26 & 19.31 & 2.65 & & \\
\hline
\end{tabular}




\begin{tabular}{|c|c|c|c|c|c|c|c|c|}
\hline \multirow{3}{*}{2} & \multirow{3}{*}{$\begin{array}{l}\text { Program } \\
\text { Effectiveness }\end{array}$} & 1 to 3 & 30 & 19.53 & 1.90 & \multirow{3}{*}{4.898} & \multirow{3}{*}{2,99} & \multirow{3}{*}{0.009} \\
\hline & & 4 to 9 & 44 & 18.77 & 2.96 & & & \\
\hline & & 10 to 33 & 26 & 20.69 & 2.13 & & & \\
\hline \multirow{3}{*}{3} & \multirow{3}{*}{ Innovation } & 1 to 3 & 30 & 15.27 & 0.16 & \multirow{3}{*}{14.66} & \multirow{3}{*}{2,99} & \multirow{3}{*}{0.00} \\
\hline & & 4 to 9 & 44 & 15.8 & 0.60 & & & \\
\hline & & 10 to 33 & 26 & 15.62 & 0.80 & & & \\
\hline \multirow{3}{*}{4} & \multirow{3}{*}{$\begin{array}{l}\text { Grassroots } \\
\text { Impact }\end{array}$} & 1 to 3 & 30 & 19.73 & 1.98 & \multirow{3}{*}{8.20} & \multirow{3}{*}{2,99} & \multirow{3}{*}{0.00} \\
\hline & & 4 to 9 & 44 & 19.32 & 1.52 & & & \\
\hline & & 10 to 33 & 26 & 19.04 & 3.19 & & & \\
\hline \multirow{3}{*}{5} & \multirow{3}{*}{$\begin{array}{l}\text { Target Group } \\
\text { Involvement }\end{array}$} & 1 to 3 & 30 & 11.73 & 0.72 & \multirow{3}{*}{5.38} & \multirow{3}{*}{2,99} & \multirow{3}{*}{0.00} \\
\hline & & 4 to 9 & 44 & 11.99 & 0.93 & & & \\
\hline & & 10 to 33 & 26 & 12.39 & 0.83 & & & \\
\hline \multirow{3}{*}{6} & \multirow{3}{*}{$\begin{array}{l}\text { Resource } \\
\text { Appreciation }\end{array}$} & 1 to 3 & 30 & 11.73 & 0.81 & \multirow{3}{*}{17.60} & \multirow{3}{*}{2,99} & \multirow{3}{*}{0.00} \\
\hline & & 4 to 9 & 44 & 11.5 & 0.22 & & & \\
\hline & & 10 to 33 & 26 & 11.77 & 0.27 & & & \\
\hline \multirow{3}{*}{7} & \multirow{3}{*}{$\begin{array}{l}\text { Project } \\
\text { Orientation }\end{array}$} & 1 to 3 & 30 & 10.57 & 0.69 & \multirow{3}{*}{6.39} & \multirow{3}{*}{2,99} & \multirow{3}{*}{0.00} \\
\hline & & 4 to 9 & 44 & 10.05 & 0.49 & & & \\
\hline & & 10 to 33 & 26 & 10.19 & 0.35 & & & \\
\hline \multirow{3}{*}{8} & \multirow{3}{*}{$\begin{array}{l}\text { Organization } \\
\text { Flexibility }\end{array}$} & 1 to 3 & 30 & 10.97 & 1.20 & \multirow{3}{*}{3.56} & \multirow{3}{*}{2,99} & \\
\hline & & 4 to 9 & 44 & 11.27 & 0.63 & & & 0.003 \\
\hline & & 10 to 33 & 26 & 11.12 & 0.39 & & & \\
\hline
\end{tabular}

(Computed from Primary Data)

The 8 table Presented mean scores and Std. Deviation of NGOs effectiveness with respect to work experience of NGOs staff as perceived by NGO staff members in all the developmental blocks (under developed, developing and developed) of Telangana region.

As regards dimensions of effectiveness of NGOs staff work experience of between 10 to 33 years are perceived majority of the dimensions of better namely "Agency Appreciation" (19.31), "Programme Effectiveness" (20.69), "Target Group Involvement" (12.19), “ Resource Appreciation" (11.77). Further it is found that those who are having three to nine years of work experience are perceived the dimensions of better namely "innovation" (15.62), and "Organisation Flexibility" (11.27). It is interestingly to note that staff having work experience between one to two years have perceived the dimensions of better namely "Grassroots Impact" (19.73) and "Project Orientation" (10.57)

The Univariate ANOVA test was conducted to measure the relationship among NGOs Effectiveness and work experience of NGOs staff. It is observed that out of eight dimensions six dimensions namely "Innovation", "Grassroots Impact", “ Target Group Involvement", "Resource Appreciation”, " Project Orientation", " Organisation Flexibility" were not significantly affected by NGOs effectiveness with respect to work experience of staff and the remaining two dimensions namely "Agency Appreciation" and "Programme Effectiveness" were significantly affected by the NGOs effectiveness with respect to the work experience as it is evident from the $\mathrm{f}$ values presented in the above table.

\section{7: Status of hypotheses testing for Effectiveness of NGOs in Telangana}

The status of hypotheses testing had been asserted with the help of f-test values obtained. The results were presented in the following table 9 . 
Table 9: Status of hypotheses testing for Organisational Effectiveness of NGOs with reference to personal characteristics of Staff

\begin{tabular}{|c|l|l|}
\hline S.No & \multicolumn{1}{|c|}{ Variables } & \multicolumn{1}{|c|}{ Significance } \\
\hline 1 & Gender and Effectiveness of NGOs & significant \\
\hline 2 & Age group and effectiveness of NGOs & Significant \\
\hline 3 & Professional qualification and effectiveness of NGOs & Significant \\
\hline 4 & Employee's designation and effectiveness of NGOs & Significant \\
\hline 5 & Place of work and effectiveness of NGOs & Significant \\
\hline 6 & Work Experience and effectiveness of NGOs & Significant \\
\hline \multicolumn{2}{|c|}{ (Computed from Primary Data) } \\
\hline
\end{tabular}

It can be observed from the table 9 that organisational effectiveness of NGOs was affected by all the NGOs staff personal characteristics namely gender, age, professional qualification, Employee's designation, place work, work experience significantly. Thus the null hypotheses "There is no variation in perceived effectiveness of NGOs according to the personal characteristics of NGOs staff" have been rejected and alternative hypotheses is accepted.

\subsection{Major Findings and Conclusion}

1. As regards dimensions of effectiveness of NGOs according to gender of the NGO staff female are perceived in the dimensions of better namely "Agency Appreciation", "Programme Effectiveness", "Resource Appreciation" and "Organisation Flexibility", than male. For further examination it is interestingly to note that male are perceived better in dimensions namely "Innovation", Grassroots impact, "Target Group Involvement" and "Project Orientation".

2. As regards dimensions of effectiveness of NGOs according to age group of the staff between 39 to 62 years are perceived the dimensions of better namely "Agency Appreciation", "Programme effectiveness", "Resource Appreciation", followed by the staff age group between 26 to 38 are perceived the dimensions of better namely "Innovation" , "Target Group Involvement", Project Orientation" than other age groups. Lastly it is interesting to note that the age group between 18 to 25 are perceived the dimensions of better namely "Grassroots Impact", "Organisation Flexibility ".

3. As regards dimensions of effectiveness of NGOs according to the staff professional qualifications of Diploma and Intermediate courses are perceived on the dimensions of better namely "Programme effectiveness" ,Innovation" and "Target Group Involvement", followed by the professional qualification of the staff of MA/M.com/MSW/MCA/MBA/M.Sc are perceived the dimensions better namely "Resource Appreciation" and "Project Orientation". For further examination it is found that staff professional qualifications of BA/B.Com/B.Sc/BSW/BCA/B.Tech are perceived the dimensions of better namely "Agency Appreciation" and "Grassroots Impact".

4. It is revealed mean scores that among the staff those who are not having any professional qualification are perceived the dimension of better namely "Organisation Flexibility" than others.

5. As regards dimensions of effectiveness of NGOs according to the staff designations of CF/ED are perceived the dimensions better namely "Agency Appreciation", "Programme Effectiveness, "Innovation", "Grassroots Impact", "Resource Appreciation". For further examination it is interestingly to note that "Programme Coordinators are perceived in the dimensions better namely “

6. Target Group Involvement" and "Organisation Flexibility". Lastly social mobilisers or community organisers perceived the dimensions of better namely "Project Orientation" than other NGO staff designations. 
7. As regards dimensions of effectiveness of NGOs according to staff place of work of those who are working at both in office and filed perceived the dimensions of better namely "Agency Appreciation", "Innovation", "Grassroots Impact", "Target Group Involvement", and "Resource Appreciation", followed by staff working at field only perceived the dimensions better namely "Project Orientation" and "Organisation Flexibility". Interestingly staffs who are working at only office perceived the dimension of better namely "Programme Effectiveness" than other staff members working at field, office and field only.

8. As regards dimensions of effectiveness of NGOs according to staff work experience of between 10 to 33 years are perceived majority of the dimensions of better namely "Agency Appreciation", "Programme effectiveness", "Target Group Involvement", "Resource Appreciation". Further it is found that those who are having three to nine years of work experience are perceived the dimensions of better namely "innovation" "Organisation Flexibility". It is interestingly to note that staff having work experience between one to two years is perceived the dimensions of better namely "Grassroots Impact" and "Project Orientation".

In conclusion, it could be stated that if NGOs want to be effective, they need to design their recruitment and selection of employees keeping in view all the background characteristics of the staff members. Houle (1989) encouraged organizations to take member diversity into account when recruiting new members. Specifically, he suggested that organizations consider the age, gender, and residential location of potential board members. Other characteristics of organizations may wish to consider include racial, ethnic, and philosophical diversity (Carver, 2006). There is a need to look at NGOs effectiveness from indigenous perspective due to the regional variations that are predominant in making NGOs effective.

\section{References}

1. Baru, R, (1998), Structural Adjustment And Health: Changing Role Of NGOs, Paper Presented At International Seminar On Global Governance And Social Policy, Baltic Sea Centre: Kellokeski.

2. Balduck, A. L., \& Buelens, M, (2008). A Two-Level Competing Values Approach to Measure Non-profit Organizational Effectiveness. Working Papers of Faculty of Economics and Business Administration, Ghent University,

3. Brown, (2008), Creating Credibility: Legitimacy and Accountability for Transnational Civil Society, Kumarian Press.

4. Carver, J. (2006). Boards that make a difference: A new design for leadership in nonprofit and public organizations (3rd ed.). San Francisco: Jossey-Bass Publishers.

5. Edwards, M. And D. Hulme (1993). "Too Close For Comfort? The Impact of Official Aid on Nongovernmental Organizations," In World Development, Volume 24.

6. Garain.S (1993).Towards A Measure of Organisational Effectiveness for Non-Governmental Organisations, The Indian Journal Of Social Work, LIV, 2.

7. Garain, (1998), Organisational Effectiveness of Non-Governmental Organisations, University Book House, Jaipur-3.

8. Georgopoulos, B. S., \& Tannenbaum, A. S. (1957). "A Study of Organizational Effectiveness". American Sociological Review, 22, 534-540.

9. Ghorpade, J., Ed. (1971) Assessment of Organizational Effectiveness: Issues, Analysis, And Readings.Pacific Palisades: Goodyear.

10. Houle,C. O. (1989). Governing boards their nature and nurture. San Francisco: Jossey-Bass Publishers House).

11. Kaldor,M.(2005) La Sociedad Civil Global, Una Respuesta A La Guerra, Barcelona:Tusquests Editores.

12. Moore, M. \& Stewart, S.(1998) “Corporate Governance For NGOs?", Development In Practice, Volume 8, Number 3

13. Mullin, 1996. "Managing The Outsourced Enterprise." Journal of Business Strategy, Jul/Aug96, 17 (4): 28-36. 
14. Rajasekar, D. (2000), Decentralized Government and NGOs: Issues, Strategies And Ways Forward, Concept Publications, New Delhi.

15. Reynolds, M. (2007), Evaluation Based on Critical Systems Hruristics. In B. Williams and I. Immam (Eds) Systems Concept in Evaluation: An Expert Anthology 9(Pp. 101-122) Point Reyes, C A: Edge Press of Inverness.

16. Scriven M. (2007) Key Evaluation Checklist. Evaluation Checklists Project, University Of Michigana vailable At Http://Www.Wmich.Edu/Evalctr/Checklists/Kec Feb2007.Pdf.

17. Sowa Jessica E, Sally Coleman, Selden and Jodi R Sandfort (2004), "No Longer Unmeasurable? A Multidimensional Integrated Model of Nonprofit Organizational Effectiveness", Nonprofit and Voluntary Sector Quarterly, Vol. 33, No. 4, pp. 711-719.

18. Thorndike, R L (1949), Personnel Selection: Test And Measurement Techniques, New York: Wiley. 